\title{
Mensagem do Mistério de Cristo: A proclamação de Jesus sobre o Reino de Deus na teologia de Joseph Ratzinger e no Magistério de Bento XVI
}

\author{
Orientador: Antonio Luiz Catelan Ferreira \\ Mestrando: Luís Carlos Pereira Santos da Silva \\ Área de Concentração: Teologia Sistemático-Pastoral \\ Linha de Pesquisa: Fé e Cultura \\ Projeto de Pesquisa: A teologia de Joseph Ratzinger - Bento XVI
}

O tema da presente pesquisa é a proclamação de Jesus sobre o Reino de Deus na teologia de Joseph Ratzinger e no Magistério de Bento XVI. O que se pretende - como objetivo principal - é investigar como essa noção é interpretada nos textos desse autor, qual o significado que tal realidade assume em seu pensamento teológico e em seu Magistério e identificar sua importância para a compreensão da figura e da mensagem de Jesus. Com esse último elemento, na realidade, se toca em um aspecto da grande e importante questão que é a relação entre a proclamação do Reino de Deus por Jesus de Nazaré e as origens da cristologia. Com isto, se visa obter um melhor esclarecimento sobre como Joseph Ratzinger/Bento XVI interpreta o Reino de Deus e de que forma ele fundamenta e aplica essa sua interpretação. Faz ainda parte do escopo da pesquisa a identificação de elementos que distinguem sua interpretação da de outros autores e, ainda, se sua interpretação sofre alguma alteração na evolução de sua obra. Como é sabido, no contexto da discussão sobre o Jesus histórico, essa problemática constitui um aspecto essencial, inúmeros autores se debruçaram sobre ela e muitas foram as interpretações que dela se ofereceram, pelo menos, desde o século XVIII, com o advento da pesquisa histórico-crítica.

Palavras-chave: Jesus Cristo. Reino de Deus. Cristologia. Joseph Ratzinger. Bento XVI. 